\title{
A novel interaction between nutrients and grazers alters relative dominance of marine habitats
}

\author{
Bayden D. Russell*, Sean D. Connell \\ Southern Seas Ecology Laboratories DP418, School of Earth and Environmental Sciences, University of Adelaide, \\ South Australia 5005, Australia
}

\begin{abstract}
Strong top-down control by grazers is considered a moderating influence on the negative effects of elevated nutrients on marine algae. Little experimental work has been done in a system that has weak grazing pressure (weak top-down control), which is also subjected to elevated nutrients. We experimentally elevated nutrient concentration to test (1) the effects of nutrient enrichment on algal assemblages in the presence and absence of canopies (Ecklonia radiata) and (2) the interactive effects of nutrients and molluscan grazers (meso-grazers) on algal assemblages in the absence of canopies. We established that the loss of canopy-forming algae is likely to be a key precursor to nutrient-driven changes of assemblages of benthic algae, because nutrients had no effects on algal assemblages in the presence of canopy-forming algae. In the absence of canopy-forming algae, space was monopolised by filamentous, turf-forming algae, and it was only in the presence of grazers that nutrients caused a change to the relative covers of algal habitat that monopolise canopyfree space. When grazers were present at natural densities, elevated nutrients reduced the monopoly of turf-forming algae in favour of foliose algae. These results demonstrate a novel interaction between nutrients (bottom-up control) and grazing pressure (top-down control), which are fundamental to predictions about management of human activities that continue to reduce densities of herbivores and increase nutrient availability on temperate coasts.
\end{abstract}

KEY WORDS: Grazing · Top-down · Bottom-up · Eutrophication · Turf-forming algae

\section{INTRODUCTION}

Massive changes to coastal habitats are forecast as a result of increasing nutrient availability from human activities (Vitousek et al. 1997, Worm et al. 1999). Grazing by herbivores can counter the effects of nutrient enrichment on algal habitats (Lotze et al. 2001, Hillebrand 2003), yet its effectiveness is likely to vary among regions of varying consumer pressure (Menge et al. 1999).

On temperate coasts, increasing nitrogen and phosphorus loading often favours small, fast-growing and opportunistic algae at the expense of slower-growing and longer-lived algae that form canopies (Worm et al. 1999). Canopies exert strong influences and form predictable associations with benthos across thousands of kilometres of coast (Fowler-Walker \& Connell 2002,
Irving et al. 2004), but they undergo relatively frequent and unpredictable loss and re-establishments within a generation (Witman 1988, Tegner et al. 1997). There is, however, an increasing trend for long-term intergenerational and perhaps permanent loss of canopy-forming algae to occur along human-impacted coasts (Jackson 2001, Eriksson et al. 2002) as a consequence of nutrient enrichment (Worm et al. 1999).

Many of the well-studied coasts of the world exist under strong consumer (grazer) control and their benthic habitats are able to moderate nutrient enrichment on macroalgal habitats (Lotze et al. 2001). However, there are large expanses of coastline, such as South Australia and West Australia, that are not strongly affected by grazing (Fowler-Walker \& Connell 2002). This may be in part explained by the sparse densities of herbivorous molluscs and urchins (Fowler-Walker \& 
Connell 2002, Vanderklift \& Kendrick 2004) compared with eastern Australia (Fletcher 1987, Andrew \& Underwood 1993) and other parts of the world (Scheibling et al. 1999, Villouta et al. 2001). The interactive effects of nutrients and grazers on coasts with few grazers are not well understood, and these coasts would seem to be most vulnerable to increases in nutrient concentration because of a lack in consumer pressure, yet there is little information to challenge or support this concern.

Turf-forming algae and foliose algae dominate space (95\% cover) outside forests of canopy-forming algae in Western and South Australia (Fowler-Walker \& Connell 2002), and turf-forming algae are the first to colonise space formed with the loss of canopies of kelp (Melville \& Connell 2001). On a relatively oligotrophic coast that lacks major grazers (South Australia), we tested (1) the effects of nutrient enrichment on algal assemblages in the presence and absence of canopies (Ecklonia radiata) and (2) the interactive effects of nutrients and grazers in the absence of canopies. We predicted that (1) elevated nutrient concentrations would have a greater effect on algal assemblage in the absence of canopies and (2) grazers would reduce the effect of elevated nutrients on algal assemblages in the absence of canopies.

\section{MATERIALS AND METHODS}

Study site and experimental units. This experiment was done on experimental reefs in Abalone Cove, West Island, South Australia $\left(35^{\circ} 36^{\prime} \mathrm{S}, 138^{\circ} 35^{\prime} \mathrm{E}\right)$ (Connell 2003b). The site consists of a sloping shore of boulders ( $30 \mathrm{~cm}$ across by $8 \mathrm{~cm}$ deep) that terminates at sand in $\sim 5 \mathrm{~m}$ depth. The experiment was run for $76 \mathrm{~d}$ from December 2002 to February 2003 during the Austral summer. Experimental reefs were $60 \times 60 \mathrm{~cm}$ metal frames on a double concrete base $(60 \times 60 \mathrm{~cm})$ set on sand ( $5 \mathrm{~m}$ depth) at least $10 \mathrm{~m}$ from the natural reef. The upper concrete base was $20 \mathrm{~cm}$ above the lower base (set on sand) and created a platform for experimental boulders. This design has been successfully used to exclude and test the effects of molluscan grazers (see Shepherd \& Turner 1985 for a photograph of the experimental reefs).

Experimental design. The effects of nutrients (ambient vs. elevated) and canopy (present vs. absent) on algal assemblages were tested in orthogonal combinations ( $\mathrm{n}=5$ reefs/treatment). To simulate natural conditions, boulders with established Ecklonia radiata kelp plants (canopy present) and boulders from open patches, devoid of canopy algae (canopy absent), were collected from the natural reef. A total of 10 boulders were placed on each experimental reef. Nine boulders from the natural reefs were placed on each experimental reef, around the edges, leaving a gap in the middle of each reef. One experimental boulder devoid of marine life, collected from above the intertidal zone, was placed in the gap in the middle of each experimental reef. The response of algae to treatments was only quantified on this central boulder, to avoid possible edge effects and possible effects of pre-existing algae. On experimental reefs where canopy was present, E. radiata densities were maintained to match natural densities seen on the adjacent reef (9 to 11 ind. $\mathrm{m}^{-2}$ ). On grazed reefs, mollusc densities were also maintained at natural densities ( 110 ind. $\left.\mathrm{m}^{-2}\right)$.

In a second experiment, the interactive effects of nutrients (ambient vs. elevated) and grazers (present vs. absent) in the absence of kelp were tested in orthogonal combinations ( $\mathrm{n}=5)$. To maintain differential grazing pressure throughout the experiment, molluscs were regularly removed (approximately every $14 \mathrm{~d})$ from ungrazed reefs to check against the occasional immigration of grazers. To maintain natural grazing pressure on grazed reefs, grazers were added from the adjacent natural reef when mollusc densities were observed to have fallen below natural densities. To assess relative difference in grazing pressure between ambient and elevated treatments, percentage cover of grazing scars of molluscs were quantified on the 'grazer' reefs $(n=5)$, using the same method as for quantification of algal assemblage (see below).

Nutrients were supplied as $12 \mathrm{~g}$ of Osmocote Plus ${ }^{\circledR}$ slow-release fertilizer per nutrient reef ( 6 mo release: $15,5,10 \mathrm{~N}-\mathrm{P}-\mathrm{K})$. This weight of fertilizer was determined from the rate of release supplied by Osmocote ${ }^{\circledR}$. Four nylon mesh bags (1 mm mesh size) were each filled with $3 \mathrm{~g}$ Osmocote ${ }^{\circledR}$ pellets and attached to the reefs at the corners of the central boulder using cable ties at the beginning of both experiments. Each bag was $\sim 2 \mathrm{~cm}$ in diameter and was slightly below the top surface of the central boulder. This configuration of deployment does not modify water flow, or increase habitable surface on the boulder, and explicit tests for artefacts associated with this experimental protocol have shown that treatments are not confounded by experimental artefacts (Gorgula \& Connell 2004). Moreover, this approach has been tested against other experimental protocols and suggested to be the most appropriate method of elevating nutrients in subtidal experiments (Worm et al. 2000).

Algal assemblages on the experimental boulders were quantified at the peak of summer (end of February), to avoid the confounding effects of algal senescence with the onset of cooler water temperatures and shorter days (lower light availability) (Worm et al. 2002). Percentage cover of algae were quantified by placing a $10 \times 10 \mathrm{~cm}$ grid containing 25 points over 
the boulder and recording the algae that occurred directly beneath each point. Algae were classified as turf-forming, foliose and macroalgae, based on morphology (see Steneck \& Dethier 1994, Fowler-Walker \& Connell 2002). Turf-forming algae were annual, fine filamentous algae that formed close-knit 'turfs', and were $<1.5 \mathrm{~cm}$ in vertical height. Foliose algae were non-branching algae, growing to $>2 \mathrm{~cm}$, but less than $5 \mathrm{~cm}$, while macroalgae and canopy-forming algae grew to over $5 \mathrm{~cm}$. The vertical height of turf-forming algae $(\mathrm{mm})$ was also recorded for each experimental boulder. Since turf-forming algae forms a 'turf' of uniform height (B. D. Russel pers. obs.), percentage covers was considered to be a reasonable proxy for biomass. The molluscan grazers in this experiment grazed algae to the substrate, so where grazing had occurred on boulders the algae were uniformly $<1 \mathrm{~mm}$ in vertical height.

Nutrient analysis. Water samples were collected at the end of February 2003 to ascertain whether nutrients were supplied at elevated rates for the duration of the experiment. To test whether the nutrient treatments on neighbouring reefs were independent, water samples were taken from nutrient-elevated reefs and their closest neighbouring ambient reef, as well as distant to all reefs (ambient water-column nutrients) $(\mathrm{n}=4)$. Samples were collected in $120 \mathrm{ml}$ vials $10 \mathrm{~cm}$ above the experimental boulders. Ambient water-column samples were taken at the same height above the natural substratum. On returning to the surface, all samples were filtered though $0.45 \mu \mathrm{m}$ filters and frozen. Samples were sent to the Australian Water Quality Centre (South Australia) for analysis.

Data analysis. Two-factor ANOVAs were used to analyse the outcomes of both experiments, and data were arc-sine-transformed to meet assumptions of homogeneity. In the first experiment, canopy (present vs. absent) and nutrients (ambient vs. elevated) were treated as fixed, orthogonal factors. In the second experiment, nutrients (ambient vs. elevated) and grazers (present vs. absent) were fixed and orthogonal factors. Where significant interaction terms were detected, Student-Newman-Keuls (SNK) comparison of means was used to determine which factors differed. Concentrations of nitrate and phosphate in the water samples were compared among treatments using a single-factor ANOVA. Statistical analysis was not possible for tests of differences in concentration of ammonium or DIN, because an error in water analysis meant that ammonium was reported for only 1 elevated water sample.

\section{RESULTS}

Molluscan grazers at the field site were dominated by Clanculus spp. (48\%), Phasianella ventricosa $(11 \%)$, Gibbula preissiana (11\%) and Turbo spp. $(10 \%)$ (Clarkson \& Shepherd 1985). Mean density of molluscan grazers on 'grazed' reefs was 111 ind. $\mathrm{m}^{-2}$ $\left( \pm \mathrm{SE}_{i} \pm 9.57\right)$, which is comparable to natural densities at the field site some 20 yr previously (mean 113.9; Clarkson \& Shepherd 1985). Turf-forming algae were primarily composed of Feldmannia lebelli and $F$. globifera (Gorgula \& Connell 2004) and foliose algae Cladosiphon filum.

Ambient water nitrate and dissolved inorganic nitrogen (DIN) concentrations at West Island (South Australia) were substantially lower than the concentrations reported in other studies (Table 1). The relatively oligotrophic waters in this study could mean that relatively small increases in nutrient concentrations will have large effects. Nitrate levels were $87 \%$ higher on

Table 1. Comparison of the ambient water concentrations $\left(\mu \mathrm{mol} \mathrm{l}^{-1}\right)$ of nitrate $\left(\mathrm{NO}_{3}\right)$ and dissolved inorganic nitrogen $(\mathrm{DIN}$ : nitrate + nitrite + ammonium) reported in this and other studies. bd: below detection limits; -: not reported

\begin{tabular}{|c|c|c|c|c|c|c|c|}
\hline Site & Region & Season & Max. $\mathrm{NO}_{3}$ & Min. $\mathrm{NO}_{3}$ & Max. DIN & Min. DIN & Source \\
\hline West Island & South Australia & Summer & 0.074 & 0.054 & 0.15 & 0.15 & This study \\
\hline West Island & South Australia & Winter & bd & bd & $0.11^{\mathrm{a}}$ & & This study \\
\hline Schlei Fjord & Germany & Summer & $0.3^{\mathrm{b}}$ & $\mathrm{bd}^{\mathrm{b}}$ & $5.81^{\mathrm{c}}$ & $1.19^{\mathrm{c}}$ & $\begin{array}{l}\text { Hillebrand et al. (2000); } \\
\text { Worm et al. (2000) }\end{array}$ \\
\hline Schlei Fjord & Germany & Winter & $160.00^{\mathrm{b}}$ & $-{ }^{\mathrm{b}}$ & $35.76^{\mathrm{c}}$ & $10.68^{\mathrm{c}}$ & $\begin{array}{l}\text { Hillebrand et al. (2000); } \\
\text { Worm et al. (2000) }\end{array}$ \\
\hline Oslofjord & Norway & Summer & - & - & 4.00 & 2.00 & Bokn et al. (2002) \\
\hline Oslofjord & Norway & Winter & - & - & 14.00 & 12.00 & Bokn et al. (2002) \\
\hline Väddö & Sweden & Spring & 2.58 & 0.3 & - & - & Hillebrand (2003) \\
\hline Väddö & Sweden & Autumn & 1.31 & - & - & - & Hillebrand (2003) \\
\hline Tatoosh Is. & Western USA & Summer & 31.5 & 1.77 & - & - & Pfister \& Van Alstyne (2003) \\
\hline Veerse Meer & The Netherlands & Summer & 0.7 & - & 0.9 & - & van Lent et al. (1995) \\
\hline
\end{tabular}


nutrient-elevated reefs (mean $0.121 \pm 0.04 \mu \mathrm{mol} \mathrm{l}^{-1}$ ) than ambient (mean $0.064 \pm 0.01 \mu \mathrm{mol} \mathrm{l^{-1 }}$; ANOVA: $\left.F_{2,3}=16.78, \mathrm{p}<0.03\right)$. SNK comparison of means showed that nitrate levels were significantly different between elevated and ambient water samples, but did not differ between ambient nutrient reefs and watercolumn samples, showing that experimental reefs were independent. Phosphate levels did not differ between ambient $\left(0.19 \pm 0.005 \mu \mathrm{mol} \mathrm{l}^{-1}\right)$ and nutrientelevated reefs $\left(0.19 \pm 0.01 \mu \mathrm{mol}{ }^{-1}\right.$; ANOVA: $F_{2,3}=3.1$, $\mathrm{p}>$ 0.15). Ammonium concentration could not be analysed because only 1 elevated nutrient sample had ammonium concentration reported from the analysis company, but this single elevated value $\left(1.22 \mu \mathrm{mol} \mathrm{l}^{-1}\right)$ was higher than the mean ambient ammonium concentration $\left(0.72 \pm 0 \mu \mathrm{mol} \mathrm{l}^{-1}\right)$.

The presence of a canopy (Ecklonia radiata) had a very large effect on algal assemblages. Kelp significantly reduced the percentage cover of turf-forming

(a) Foliose algae

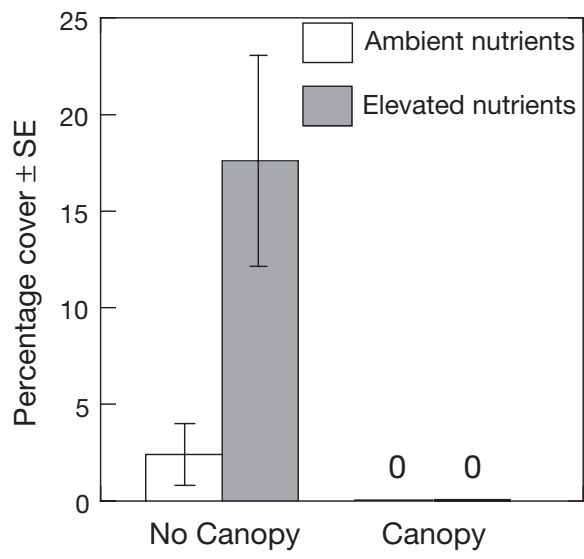

(b) Turf-forming algae

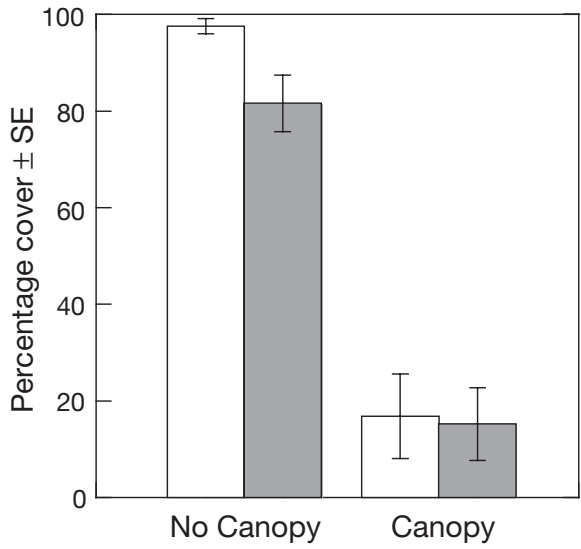

Fig. 1. Effect of canopy (no canopy vs. canopy) and nutrients (ambient vs. elevated) on the percentage cover of (a) foliose algae and (b) turf-forming algae (mean $\pm \mathrm{SE}, \mathrm{n}=5$ ). Values above the bars in (a) show $0 \%$ cover
Table 2. Results of the 2-way ANOVAs testing the effects of canopy (absent vs. present) and nutrients (ambient vs. elevated) on the percentage cover of (i) foliose and (ii) turfforming algae. df: degrees of freedom; MS: mean square. ns: non-significant, $\mathrm{p}>0.05 ;{ }^{* *} \mathrm{p}<0.01 ;{ }^{* * *} \mathrm{p}<0.0001$. Arc-sine transformations were used on (i) and (ii) to meet assumptions of homogeneity of data (Cochran's $C$-test)

\begin{tabular}{|lrrcccrrr|}
\hline Source & $\mathrm{df}$ & $\begin{array}{c}\text { MS } \\
\text { Foliose }\end{array}$ & $F$ & $\mathrm{p}$ & $\begin{array}{c}\text { MS } \\
\text { Turf-forming }\end{array}$ & $F$ & $\mathrm{p}$ \\
\hline Canopy & 1 & 1064.49 & 26.99 & ${ }^{* * *}$ & 15628.04 & 84.12 & ${ }^{* * *}$ \\
Nutrient & 1 & 404.79 & 10.26 & ${ }^{* *}$ & 386.81 & 2.08 & $\mathrm{~ns}$ \\
$\mathrm{C} \times \mathrm{N}$ & 1 & 404.79 & 10.26 & ${ }^{* *}$ & 470.00 & 2.53 & $\mathrm{~ns}$ \\
Residual & 16 & 39.43 & & & 185.78 & & \\
\hline
\end{tabular}

algae regardless of nutrient concentration (Fig. 1, Table 2). Importantly, foliose algae, which naturally have sparse percentage covers relative to turf-forming algae, were most extensive in the presence of both grazers and elevated nutrients on reefs without kelp (Fig. 1, Table 2). The failure to detect the effects of nutrients on turf-forming algae in the absence of kelp $(\mathrm{C} \times \mathrm{N}$ interaction; $\mathrm{p}=0.13)$ indicates the large spatial variance in cover of these algae in response to elevated nutrients (Fig. 1, Table 2).

In the absence of kelp (open reefs), treatments interacted so that nutrients had no effect on the percent cover of foliose or turf-forming algae unless grazers were present. The percentage cover of foliose algae was greater when grazers and elevated nutrients were present in combination (mean $\pm \mathrm{SE} ; 17 \pm 5 \%$; Fig. 2, Table 3). In contrast, the percentage cover of turfforming algae was less when nutrients and grazers were present in combination ( $81 \pm 5 \%$; Fig. 2 , Table 3$)$. The vertical height of turf-forming algae, where it had not been grazed, did not differ between treatments (no grazers, ambient nutrients: $10.6 \pm 1.17 \mathrm{~mm}$; no grazers, elevated nutrients: $9.4 \pm 0.87 \mathrm{~mm}$; grazers, ambient nutrients: $10.4 \pm 0.75 \mathrm{~mm}$; grazers, elevated nutrients: $9.0 \pm 1.4 \mathrm{~mm}$; ANOVA: all p > 0.25), indicating that percentage cover of algae is a good measure of treatment effects. On grazed reefs, the mean percentage cover of grazing scars by molluscs was greater on nutrient-elevated reefs (mean $\pm \mathrm{SE} ; 44 \pm 6.1 \%$ ) than on ambient reefs $\left(20 \pm 4.8 \%\right.$; ANOVA: $F_{1,8}=9.46, \mathrm{p}=$ 0.015).

\section{DISCUSSION}

A key finding was that slight increases in enrichment of oligotrophic waters are unlikely to have substantial effects on benthos when kelp forests are present. Like Bokn et al. (2002), it appears that the effects of elevated nutrients require some other perturbation that 
(a) Foliose algae

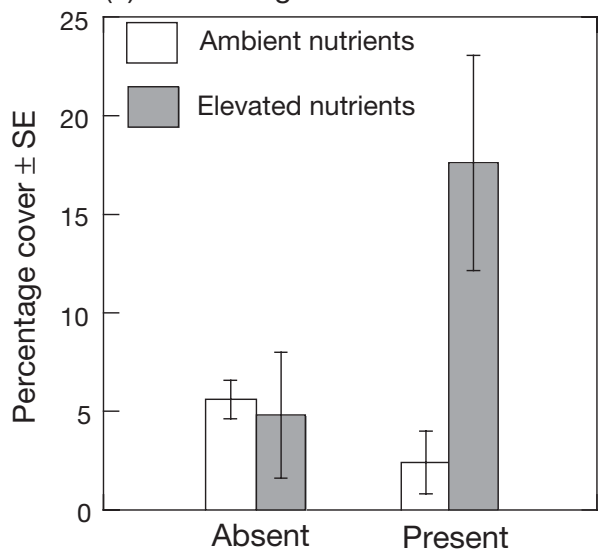

(b) Turf-forming algae

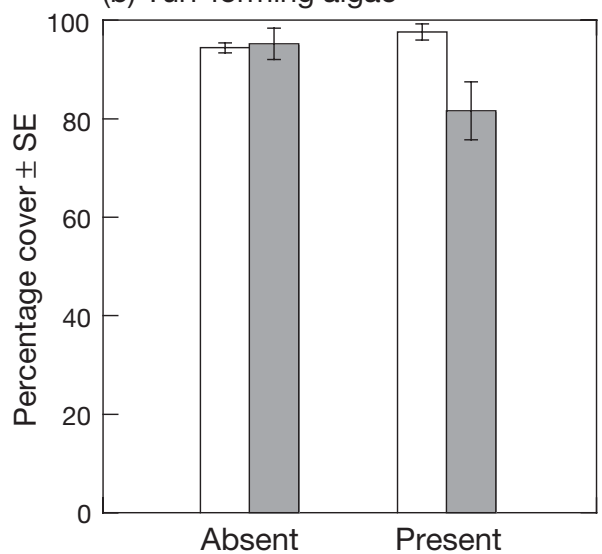

Fig. 2. Effect of grazing (absent vs. present) and nutrients (ambient vs. elevated) on percentage cover of (a) foliose algae and (b) turf-forming algae on reefs without canopy (mean $\pm \mathrm{SE}, \mathrm{n}=5$ )

Table 3. (a) Results of 2-way ANOVAs testing the effects of grazing (absent vs. present) and nutrients (ambient vs. elevated) on the percentage cover of foliose and turf-forming algae on reefs without canopy. (b) SNK tests on interaction term (grazing $\times$ nutrients). Statistical terms as in Table 2

\begin{tabular}{|c|c|c|c|c|c|c|c|}
\hline $\begin{array}{l}\text { (a) ANOV } \\
\text { Source }\end{array}$ & $\begin{array}{l}\text { As } \\
\text { df }\end{array}$ & $\begin{array}{c}\text { MS } \\
\text { Foliose }\end{array}$ & $F$ & & $\begin{array}{l}\text { MS } \\
\text { rf-formi }\end{array}$ & $F$ & $\mathrm{p}$ \\
\hline Grazing & 1 & 73.85 & 1.01 & ns & 83.78 & 1.11 & ns \\
\hline Nutrient & 1 & 195.40 & 2.68 & ns & 211.35 & 2.79 & ns \\
\hline $\mathrm{G} \times \mathrm{N}$ & 1 & 689.59 & 9.47 & $* *$ & 719.29 & 9.49 & $* *$ \\
\hline Residual & 16 & 72.84 & & & 75.77 & & \\
\hline \multicolumn{8}{|c|}{ (b) SNK tests } \\
\hline & & & \multicolumn{2}{|c|}{ Foliose } & \multicolumn{3}{|c|}{ Turf-forming } \\
\hline \multicolumn{3}{|c|}{ Ambient nutrients } & \multicolumn{2}{|c|}{$\begin{array}{l}\text { grazers = } \\
\text { no grazers }\end{array}$} & \multicolumn{3}{|c|}{$\begin{array}{l}\text { grazers = } \\
\text { no grazers }\end{array}$} \\
\hline \multicolumn{3}{|c|}{ Elevated nutrients } & \multicolumn{2}{|c|}{$\begin{array}{l}\text { grazers > } \\
\text { no grazers }\end{array}$} & \multicolumn{3}{|c|}{$\begin{array}{l}\text { grazers < } \\
\text { no grazers }\end{array}$} \\
\hline
\end{tabular}

leads to the removal of macroalgae before changes in algal assemblages are observed. Kelp has strong negative effects on the cover of turf-forming algae (Connell 2003a), which trap sediment and inhibit the recolonisation of Ecklonia radiata (Kennelly 1987) and other canopy-forming algae (Devinny \& Volse 1978, Sousa et al. 1981).

An unexpected result was that the relative cover of algae that colonise in the absence of canopies will not be a simple response to nutrient elevation. In the absence of grazers, the relative covers of turf-forming and foliose algae were unaffected by nutrients. If grazers are absent, turf-forming algae monopolise space at low or high nutrient concentrations. However, it is only in the presence of grazers that elevated nutrients can have positive effects on the cover of foliose algae relative to turf-forming algae. This finding contrasts with those of Hillebrand (2003), who showed that grazers and nutrients have opposing effects on algal assemblages. In this experiment, some mechanism appears necessary to create space for potential colonisers, such as the clearance of space by grazers (Menge \& Lubchenco 1981, Hughes 1994), before nutrients can modify the relative covers of benthos, particularly habitats that are monopolised by a species or set of taxa.

This experiment demonstrates that grazing alone (top-down control) does not determine algal assemblages, because its effects are modified by nutrients. Many models may account for this observation, but a common observation from rocky-intertidal and saltmarsh habitats has been that molluscs consume relatively more nutrient-rich plants (Hillebrand et al. 2000, Silliman \& Zieman 2001). In this experiment, molluscs grazed almost twice the amount (percentage cover) of turf-forming algae exposed to elevated than ambient nutrients, indicating that grazers were selectively consuming more turf-forming algae exposed to elevated nutrients. However, we do not have data on the nutrient content of the algae, and further study is required. This mechanism could explain why grazing reduced percentage cover of turf-forming algae more in the presence than in the absence of elevated nutrients. Alternatively, foliose algae may be better competitors for space that is cleared by grazing under elevated nutrients, which could be tested by manually clearing space in the absence of grazers under ambient and elevated nutrients.

In contrast to turf-forming algae, foliose algae increased in percentage cover when elevated nutrients and grazers were present in combination. It seems that molluscs consume more turf-forming algae that have been exposed to elevated nutrients, but do not consume more foliose algae. The molluscs in this experiment can be classified as 'bulldozer' types (sensu Sommer 1999), which consume small filamentous al- 
gae down to the substrate (Clarkson \& Shepherd 1985). These molluscs are often seen grazing on boulders with smaller algae $(<2 \mathrm{~cm})$, and not the larger macroalgae (B. D. Russell pers. obs.). The foliose algae in this experiment grow to be larger (up to $10 \mathrm{~cm}$ ) than the filamentous turfs (up to $1.5 \mathrm{~cm}$ ) and may be more difficult for the molluscs to consume, possibly explaining why the foliose algae was not consumed under elevated nutrient conditions. Alternatively, growth of the foliose algae may be faster when exposed to elevated nutrients, so they rapidly reach a size too large for the molluscs to consume, both of which need further study.

The elevated nutrient levels used in this experiment are lower than those used in most studies to date (see review by Worm et al. 2000). They were also an order of magnitude less than those recorded in some local estuary mouths and similar to nutrient levels on adjacent metropolitan reefs (Gaylard 2004). These results have profound implications for forecasts of changes to benthic habitats. If turf-forming algae inhibit the recruitment of canopy-forming algae (Devinny \& Volse 1978, Sousa et al. 1981, Kennelly 1987), any process that reduces its rapid expansion will improve the conditions in which stands of canopy-forming algae are maintained and even recover. The loss of canopyforming algae typically results in the immediate colonisation and spatial dominance of turf-forming algae (Cederwall \& Elmgren 1990, Benedetti-Cecchi et al. 2001, Melville \& Connell 2001), but foliose algae tend to colonise more slowly and in sparser covers. In the presence of nutrients, foliose algae appear to do well, but only if grazers are present. It appears that grazers reduce the covers of turf-forming algae, thereby providing space for foliose algae to colonise and out-compete turf-forming algae under conditions of enhanced nutrients.

In conclusion, there are no studies that we are aware of which show that the relative dominance of algae is affected by an interaction where grazers need to be present before the positive effects of nutrients take control. In the current context, management strategies that conserve or increase grazing pressure (e.g. Marine Protected Areas) would be an important consideration when managing coastal eutrophication. If the worldwide increase in nutrient enrichment of temperate coasts also occurs in South Australia, grazers could be an important check on the expansion of turfforming algae whose monopolisation of habitat is more rapid in the absence of grazers.

Acknowledgements. We thank A. D. Irving, without whom the fieldwork for this project would never have been possible. Thanks to T. E. Minchinton and B. Worm, who made comments that substantially improved the manuscript. This research was funded by an APA to B.D.R. and an ARC Discovery grant to S.D.C.

\section{LITERATURE CITED}

Andrew NL, Underwood AJ (1993) Density-dependent foraging in the sea urchin Centrostephanus rodgersii on shallow subtidal reefs in New South Wales, Australia. Mar Ecol Prog Ser 99:89-98

Benedetti-Cecchi L, Pannacciulli F, Bulleri F, Moschella PS, Airoldi L, Relini G, Cinelli F (2001) Predicting the consequences of anthropogenic disturbance: large-scale effects of loss of canopy algae on rocky shores. Mar Ecol Prog Ser 214:137-150

Bokn TL, Moy FE, Christie H, Engelbert S and 7 others (2002) Are rocky shore ecosystems affected by nutrient-enriched seawater? Some preliminary results from a mesocosm experiment. Hydrobiologia 484:167-175

Cederwall H, Elmgren R (1990) Biological effects of eutrophication in the Baltic Sea, particularly the coastal zone. Ambio 19:109-112

Clarkson PS, Shepherd SA (1985) Distribution and feeding of archaeogastropods in a boulder habitat at West Island, South Australia. J Malac Soc Aust 7:35-44

Connell SD (2003a) The monopolization of understorey habitat by subtidal encrusting coralline algae: a test of the combined effects of canopy-mediated light and sediment. Mar Biol 142:1065-1071

Connell SD (2003b) Negative effects overpower the positive of kelp to exclude invertebrates from the understorey community. Oecologia 137:97-103

Devinny JS, Volse LA (1978) Effects of sediments on the development of Macrocystis pyrifera gametophytes. Mar Biol 48:343-348

Eriksson BK, Johansson G, Snoeijs P (2002) Long-term changes in the macroalgal vegetation of the inner Gullmar Fjord, Swedish Skagerrak coast. J Phycol 38: 284-296

Fletcher WJ (1987) Interactions among subtidal Australian sea urchins, gastropods, and algae: effects of experimental removals. Ecol Monogr 57:89-109

Fowler-Walker MJ, Connell SD (2002) Opposing states of subtidal habitat across temperate Australia: consistency and predictability in kelp canopy-benthic associations. Mar Ecol Prog Ser 240:49-56

Gaylard S (2004) Ambient water quality of the Gulf St. Vincent metropolitan coastal waters. Rep no 2, Environmental Protection Authority, Adelaide

Gorgula SK, Connell SD (2004) Expansive covers of turf-forming algae on human-dominated coast: the relative effects of increasing nutrient and sediment loads. Mar Biol 145: $613-619$

Hillebrand H (2003) Opposing effects of grazing and nutrients on diversity. Oikos 100:592-600

Hillebrand H, Worm B, Lotze HK (2000) Marine microbenthic community structure regulated by nitrogen loading and grazing pressure. Mar Ecol Prog Ser 204:27-38

Hughes TP (1994) Catastrophes, phase shifts, and large-scale degradation of a Caribbean coral reef. Science 265: $1547-1551$

Irving AD, Connell SD, Gillanders BM (2004) Local complexity in patterns of canopy-benthos associations produces regional patterns across temperate Australasia. Mar Biol 144:361-368

Jackson JBC (2001) What was natural in the coastal oceans? Proc Natl Acad Sci USA 98:5411-5418

Kennelly SJ (1987) Inhibition of kelp recruitment by turfing algae and consequences for an Australian kelp community. J Exp Mar Biol Ecol 112:49-60

Lotze HK, Worm B, Sommer U (2001) Strong bottom-up and 
top-down control of early life stages of macroalgae. Limnol Oceanogr 46:749-757

Melville A, Connell SD (2001) Experimental effects of kelp canopies on subtidal coralline algae. Austral Ecol 26: 102-108

Menge BA, Lubchenco J (1981) Community organization in temperate and tropical rocky intertidal habitats: prey refuges in relation to consumer pressure gradients. Ecol Monogr 51:429-450

Menge BA, Daley BA, Lubchenco J, Sanford E, Dahlfoff E, Halpin PM, Hudson G, Burnaford JL (1999) Top-down and bottom-up regulation of New Zealand rocky intertidal communities. Ecol Monogr 69:297-321

Pfister CA, Van Alstyne KL (2003) An experimental assessment of the effects of nutrient enhancement on the intertidal kelp Hedophyllum sessile (Laminariales, Phaeopyceae). J Phycol 39:285-290

Scheibling RE, Hennigar AW, Balch T (1999) Destructive grazing, epiphytism, and disease: the dynamics of sea urchin-kelp interactions in Nova Scotia. Can J Fish Aquat Sci 56:2300-2314

Shepherd SA, Turner JA (1985) Studies on southern Australian abalone (genus Haliotis). VI. Habitat preference, abundance and predators of juveniles. J Exp Mar Biol Ecol 93:285-298

Silliman BR, Zieman JC (2001) Top-down control of Spartina alterniflora production by periwinkle grazing in a Virginia salt marsh. Ecology 82:2830-2845

Sommer U (1999) The impact of herbivore type and grazing pressure on benthic microalgal diversity. Ecol Lett 2:65-69

Sousa WP, Schroeter SC, Gaines SD (1981) Latitudinal variation in intertidal algal community structure: the influences of grazing and vegetative propagation. Oecologia 48: 297-307

Editorial responsibility: Otto Kinne (Editor-in-Chief), Oldendorf/Luhe, Germany
Steneck RS, Dethier MN (1994) A functional group approach to the structure of algal-dominated communities. Oikos 69:476-498

Tegner MJ, Dayton PK, Edwards PB, Riser KL (1997) Largescale, low-frequency oceanographic effects on kelp forest succession: a tale of two cohorts. Mar Ecol Prog Ser 146: $117-134$

Vanderklift MA, Kendrick GA (2004) Variation in abundances of herbivorous invertebrates in temperate subtidal rocky reef habitats. Mar Freshw Res 55:93-103

van Lent F, Verschuure JM, van Veghel MLJ (1995) Comparative study on populations of Zostera marina L. (eelgrass): in situ nitrogen enrichment and light manipulations. J Exp Mar Biol Ecol 185:55-76

Villouta E, Chadderton WL, Pugsley CW, Hay CH (2001) Effects of sea urchin (Evechinus chloroticus) grazing in Dusky Sound, Fiordland, New Zealand. NZ J Mar Freshw Res 35:1007-1024

Vitousek PM, Howarth RW, Likens GE, Matson PA, Schindler DW, Schlesinger WH, Tilman DG (1997) Human alteration of the global nitrogen cycle: sources and consequences. Ecol Appl 7:737-750

Witman JD (1988) Stability of Atlantic kelp forests. Trends Ecol Evol 3:285-286

Worm B, Lotze HK, Boström C, Engkvist R, Labanauskas V, Sommer U (1999) Marine diversity shift linked to interactions among grazers, nutrients and propagule banks. Mar Ecol Prog Ser 185:309-314

Worm B, Reusch TBH, Lotze HK (2000) In situ nutrient enrichment: methods for marine benthic ecology. Int Rev Hydrobiol 85:359-357

Worm B, Lotze HK, Hillebrand H, Sommer U (2002) Consumer versus resource control of species diversity and ecosystem functioning. Nature 417:848-851

Submitted: May 19, 2004; Accepted: December 21, 2004 Proofs received from author(s): March 7, 2005 